Ann. Biol. anim. Bioch. Biophys., I975, 15 (2), 329-343.

\title{
LOW FERTILITY IN NURSING EWES DURING THE NON-BREEDING SEASON
}

\author{
Y. COGNIE, M. HERNANDEZ-BARRETO et J. SAUMANDE \\ With technical assistance of D. Andre, F. Berthelot and J. Bezard \\ Station de Physiologie de la Reproduction, \\ Centre de Recherches de Tours, I. N.R. A., \\ B. P. 1, Nouzilly, 37380 Monnaie (France)
}

\section{SUMMARY}

In the Ile-de-France ewe which has a marked sexual season, oestrus and ovulation can be efficiently controlled by progestagen-PMSG treatment, regardless of the month of the year. However, the fertility after artificial insemination at the induced oestrus increases with the interval from parturition to AI, in spring as well as autumn. The lambing rates after AI 45 or 70 days after parturition are respectively autumn, $45 \mathrm{p}$. Ioo vs $70 \mathrm{p}$. Ioo, spring, $27 \mathrm{p}$. IOO $v s 4^{6} \mathrm{p}$. Ioo.

In the case of a parturition-AI interval of 45 days, necessary for a two-lambings-per-year programme the lowest fertility is found in nursing ewes during the period of lactation anoestrus.

When a ewes is nursing two lambs, this fertility at the induced oestrus is lower than if only one lamb was suckling, especially in spring ( 48 p. Ioo vs $6 \mathbf{r}$ p. Ioo). A physiological study was conducted in the two extreme cases of dry and nursing Ile-de-France ewes receiving progestagenPMSG treatment during the months of March-May.

The recovery rate of eggs at 2 days ( 58 vs 75 p. IOo) or of blastocysts at 7 days ( 46 vs 80 p. xoo) after ovulation is lower in nursing than in dry ewes. The fertilization rate varies at the same time and in the same way.

A reciprocal egg transfer experiment between nursing and dry ewes showed that the quality of the eggs otained from nursing ewes could be implicated as a cause of the decrease in fertility. But it appears also from this transfer experiment that the quality of the uterine environment is undoubtedly unfavorable in nursing ewes : a higher embryonic mortality occurs between 18 and 50 days when eggs from dry ewew are transferred to nursing ewes than when transferred to other dry ewes. In addition, a greater number of blastocysts show a delay in development 7 days after ovulation, and the viability of fertilized eggs is reduced in nursing ewes.

The endocrine balance which precedes and follows ovulation is different in nursing ewes compared to dry ewes : the pre-ovulatory discharge of oestrogens which reflects the follicular stimulation does not evolve in the same way, nor reach the same concentrations in nursing ewes. The level of plasma progesterone is correlated with the level of plasma oestradiol i $7 \beta$ during the 24 hours before the LH peak. Also, the plasma concentration of progesterone between the Ioth and $\mathrm{r}_{4}$ th days of pregnancy is lower in nursing ewes than in dry ewes.

A decrease in the interval between lambings rapidly increases the number of young born per female per year. But, the breeding activity after parturition is only possible when ovarian activity and oestrous behaviour have been resumed. The 
duration of post-partum anoestrus in the ewe varies with the season at lambing, breed and the presence or absence of lactation and a lamb (see review by MAULEON and Flamant, I975).

The induction of oestrus and of subsequent gestation during post-partum anoestrus in the ewe has been made possible by the use of vaginal sponges impregnated with fluorogestone acetate (FGA) and injection of PMSG, even in breeds which have a marked sexual season, no matter what the season (THrMONIER et al., I968). This technique is now widely used in France, in particular as an aid during the mating period in February-March, to obtain three lambing periods in two years. However, under conditions approaching two lambings per year, that is, a lambing-breeding interval of around I I/2 months, the conception rate at the induced oestrus is often unsatisfactory (COGNIE and CoLAS, Ig68; ThIMONIER and Mauleon, rg69; Thimonier and Cognie, I97I). The influence of lactation and of the presence of a lamb on fertility, and the analysis of the physiological reasons for this decreased fertility in the nursing ewe treated during the non-breeding season will be discussed in this report.

\section{I. -- INFLUENCE OF LACTATION AND NURSING ON REPRODUCTION CONTROLLED BY PROGESTAGEN AND PMSG IN THE EWE}

The following data were collected during the three years I970-I972 from flocks of the Ile-de-France (350 females) and Prealpes du Sud (I50 females) breeds, kept in folds at I. N. R. A., Nouzilly.

The animals were treated with hormones and artificially inseminated according to different schemes established for the breed and time of year spring (I5 AprilI5 May), autumn (October-November) (table I). When the lambs were removed from their mothers, this was done at I2 and 24 hours after birth, in order to limit or prevent lactation in the ewes.

TABIE I

Treatments used to induce reproduction in nursing sheep

From Colas et al., I97 I Thimonnier and Cognie, r97I

\begin{tabular}{|c|c|c|c|c|c|}
\hline & \multicolumn{2}{|c|}{ FGA sponges } & \multirow[b]{2}{*}{$\begin{array}{c}\text { PMSG IM } \\
\text { (IU) at sponge } \\
\text { removal }\end{array}$} & \multicolumn{2}{|c|}{$\mathrm{AI} \times 2$} \\
\hline & $\begin{array}{l}\text { dose } \\
\text { (mg) }\end{array}$ & $\begin{array}{c}\text { time } \\
\text { (days) }\end{array}$ & & $\begin{array}{l}\text { interval } \\
\text { sponge } \\
\text { removal-AI } \\
\text { (hours) }\end{array}$ & $\begin{array}{c}\text { b. } \\
\text { sperm/dose } \\
\left(\times 10^{6}\right)\end{array}$ \\
\hline Autumn & 40 & 12 & $500-600$ & $50 \pm 2$ & 500 \\
\hline Spring & 30 & 12 & $600-800$ & $60 \pm 2$ & \\
\hline
\end{tabular}




\section{A. - Relationship between fertility and interval lambing-breeding activity}

The conception rate at the induced oestrus increases with the interval parturition-artificial insemination. But the figure is less, whatever this interval, when the reproductive induction occurs in spring instead of autumn. The difference in fertility between inseminations performed 43 and 70 days after lambing (table 2) is greater for the Ile-de-France breed than for the Prealpes.

\section{TABLE 2}

Conception rate at induced oestrus of autumn and spring breeding ewes.

Influence of race and interval parturition-AI

From Cognie et al., I974

\begin{tabular}{|c|c|c|c|}
\hline \multirow{2}{*}{ Season } & \multirow{2}{*}{$\begin{array}{c}\text { Interval } \\
\text { parturition-AI }\end{array}$} & \multicolumn{2}{|c|}{ Conception rate for breed } \\
\hline & & He de France & Préalpes \\
\hline Autumn & $\begin{array}{l}43 \\
70\end{array}$ & $\begin{array}{ll}45 & (89)^{*} \\
71^{*} & (55)\end{array}$ & $\begin{array}{ll}60 & (60) \\
68 & (\mathbf{4 1})\end{array}$ \\
\hline Spring & $\begin{array}{l}43 \\
70\end{array}$ & $\begin{array}{l}27 \quad\left({ }^{4}+26\right)^{*} \\
46^{*}(76)^{*}\end{array}$ & $\begin{array}{lr}45 & (178) \\
70^{*} & (51)\end{array}$ \\
\hline
\end{tabular}

( ) : Nb. of treated ewes.

* $: \mathrm{P}<0,01$.

This relation between the fertility at the induced oestrus and the interval parturition-artificial insemination was calculated from results obtained from a flock of 2000 ewes of the Prealpes breed treated according to the control of the cycle indicated in table $I$. There is a linear correlation between the interval parturitionartificial insemination and the conception rate at induced oestrus for Ile-de-France ewes suckling a single lamb, but this correlation is higher after a treatment in autumn $(r=0.96)$ than in spring $(r=0.76)$. No relationship exists between the fertility and this interval of more than 48 days if parturiton and breeding occur in spring; then, there is a significant difference between the conception rate obtained in autumn and that in spring for intervals of lambing to artificial insemination of equal or greater than $5^{2}$ days. When reproduction is resumed in autumn, the fertility continues to improve as the interval parturition-AI increases (fig. I).

A similar influence of the parturition-artificial insemination interval on litter size at induced oestrus has appeared, regarless of season, in these same Ile-de-France ewes suckling one lamb. The differences in litter size which might have existed according to season have been corrected by increasing the dose of PMSG in spring (table 3).

Several factors which modify the conception rate have became apparent : number of lambs suckled, number of lambs born, level of lactation. 


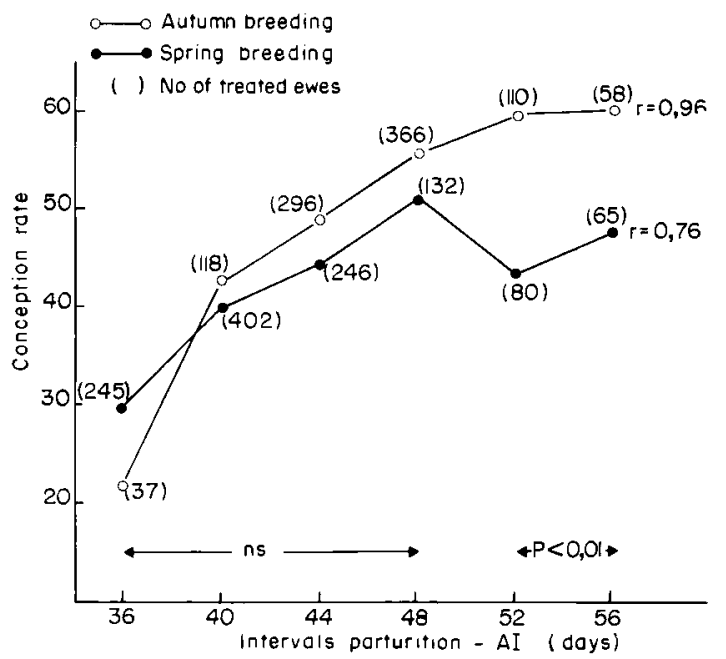

FIG. I. - Conception rate at induced oestrus of Ile-de-France eqes mursing one lamb. Influence of season and interval parturition-AI

TABLE 3

Mean litter size after $A I$ at induced oestrus (FGA-PMSG)

of females Ile-de-France nursing one lamb.

Influence of scason and interval parturition-AI

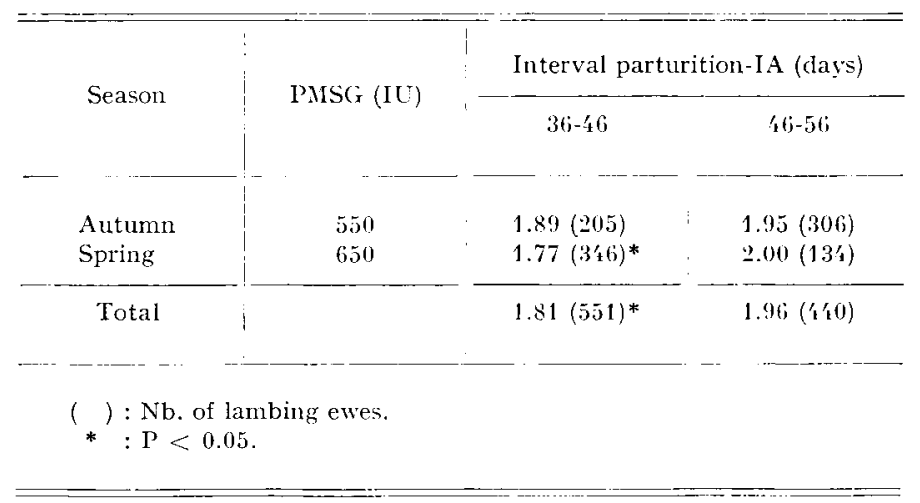

\section{B. - Infuence of number of lambs suckled}

The conception rate at the oestrus induced by a treatment FGA-PMSG in spring is significantly less for ewes suckling two lambs, regardless of the parturition-artificial insemination interval, but the decrease in fertility is more marked 70 days after parturition than at 43 days. In autumn, however, it is only during this longer interval after lambing that a difference in fertility becomes apparent between ewes suckling one and two lambs (table 4). 
This influence is no doubt related to the increase in the level of lactation of the ewes suckling two lambs. It is for this reason that the difference in fertility is more marked at 70 days than at 43 days, no doubt because the parturition-artificial insemination interval must be sufficient for a difference in milk production to be established between the two types of lactating ewe. Nevertheless, HulET and STORMSHAK (I972) also reported the effect of the number of suckled lambs on the fertility of ewes bred between 34 and 50 days post-partum.

TABI,E 4

Conception rate of autumn and spring breeding ewes at induced oestrus. Influence of number of lambs suckled and interval parturition-AI

\begin{tabular}{|c|c|c|c|}
\hline \multirow{2}{*}{ Season } & \multirow{2}{*}{$\begin{array}{c}\text { No. of lambs } \\
\text { suckled }\end{array}$} & \multicolumn{2}{|c|}{ Interval parturition-AI (days) } \\
\hline & & 43 & 70 \\
\hline Autumn & $\begin{array}{l}1 \\
2\end{array}$ & $\begin{array}{ll}53 & (77) \\
43 & (42)\end{array}$ & $\begin{array}{l}78(92) \\
57(33)^{*}\end{array}$ \\
\hline Spring & $\begin{array}{l}1 \\
2\end{array}$ & $\begin{array}{l}37(312) \\
28(186)^{*}\end{array}$ & $\begin{array}{l}65(70) \\
53(39)^{* *}\end{array}$ \\
\hline $\begin{aligned} & \text { ) }: \text { No. } \\
& * \quad: \mathrm{P}\end{aligned}$ & $\begin{array}{l}\text { ted ewes. } \\
\qquad * *: P\end{array}$ & & \\
\hline
\end{tabular}

We have also observed that the fertility in ewes suckling two lambs at the induced oestrus is lower when these lambs have a better growth rate resulting from a greater milk production (CoGNIE et al., 1974).

The suppression of lactation from the time of parturition improves the fertility at the oestrus induced 50-58 days after parturition by I 2 p. IOo ( 67 p. Ioo vs 55 p. IOo) in autumn, and by Io p. IOO (55 p. IOo vs 45 p. IOo) in spring. Such an effect has also been observed for a controlled reproduction after spring lambing, 42 days after parturition in cross-bred Romanov $\times$ Limousine ewes ('THERIEZ and MOLENAT, I975) although this was not seen in autumn in this same breed, nor in the Charmoise ewe which produces little milk, regardless of season.

\section{C. - Infuence of number of lambs born}

The suppression of lactation immediately after lambing in fact improves the fertility more efficiently in ewes having born only one lamb than in ewes with two lambs born (COGNIE et al., I974). In spring, the conception rate at induced oestrus is significantly lower in ewes weaned after bearing two lambs; than in ewes with one young born. The uterus could take longer, in this case, to return to its normal state (table 5). 
TABLE 5

Conception rate of non lactating females $\left.{ }^{(}\right)$at induced oestrus. Influence of number of lambs born/female (Ile-de-France)

\begin{tabular}{|c|c|c|c|}
\hline \multirow{2}{*}{ Season } & \multirow{2}{*}{$\begin{array}{l}\text { Interval } \\
\text { parturition-AI } \\
\text { (days) }\end{array}$} & \multicolumn{2}{|c|}{ No. of lambs born/female } \\
\hline & & 1 & 2 \\
\hline $\begin{array}{l}\text { Autumn } \\
\text { Spring }\end{array}$ & $\begin{array}{l}50 \\
58\end{array}$ & $\begin{array}{l}63(47) \\
61(28)^{*}\end{array}$ & $\begin{array}{l}70(44) \\
48(27)\end{array}$ \\
\hline \multicolumn{4}{|c|}{$\begin{array}{l}\text { ( ) : No, of treated cwes. } \\
\text { (1) Lambs removed one day after parturition. } \\
*^{*}: P<0.01 .\end{array}$} \\
\hline
\end{tabular}

\section{II. - PHYSIOLOGICAL CAUSES FOR DECREASED FERTILITY}

\section{IN NURSING EWES DURING THE NON-BREEDING SEASON}

The restoration of the uterus after lambing takes longer in nursing ewes than in dried ewes. Also, the elimination of cellular debris, and the return to normal uterine weight take place later in spring (45 days) than in autumn (30 days) (CHoFFARDET, I97I). After spring lambing, $30 \mathrm{p}$. IOO of nursing ewes still have cellular debris in the uterus at 24 days post-partum, while in dried ewes, none are found in this state (FOOTE, I97I). In addition, the number of spermatozoa necessary for artificial insemination, and the number of artificial inseminations, are much greater in nursing than in dried ewes (CoLAs et al., I97I).

The induction of ovulation asks for higher doses of the hormone PMSG in nursing ewes than in dry ewes, for all ewes to ovulate (THIMONIER et al., I968). As a result, the number of ovulations is more variable in lactating animals : ewes with four or more ovulations represent $27 \mathrm{p}$. Ioo of dry ewes treated, and 42 p. IOO of nursing ewes (ChOFFARde'T, I97I ; PraYer, I972 ; Hernandez-BarRETO, I973). Ovulations are spread over a longer period in the latter group, where $42 \mathrm{p}$. Ioo of ovulations have not yet occured in the 30 hours which follow the onset of oestrus (56-72 hr. after the end of treatment). All ovulations have occured in dry ewes by this time (SIGNORET and CoGNIE, I975). This result has been confirmed by the study of the age of the corpora lutea of ewes killed four days after the end of treatment, that is, 24-40 hours after ovulations (CoGNIE, unpublished).

Three experiments were carried out to try to evaluate the recovery rate of eggs, after perfusion, their fertilization rate and viability, by a series of comparisons between dry and nursing Ile-de-France ewes treated during the non-breeding season according to the protocol summarized in table 6 . Compared to the number of corpora lutea, the recovery rate of eggs after flushing of oviduct two days after ovulation 
TABLE 6

Treatments used for the production of eggs

in the Ile-de-France ewe during seasonal anoestrus (March-April-May)

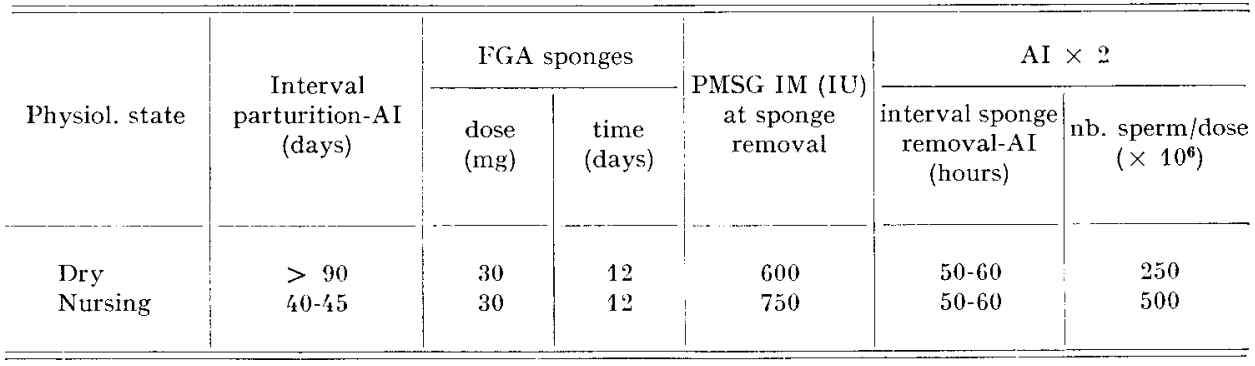

TABLE 7

Recovery rate after perfusion and percentage of segmented eggs two days after ovulation in Ile-de-France ewes treated during seasonal anoestrus

\begin{tabular}{l|c|c|c|c}
\hline \hline Physiol. state & Nb. of females & $\begin{array}{c}\text { Ovulation rate } \\
\text { (range) }\end{array}$ & $\frac{\text { Nb. eggs recovered }}{\text { Total corpora lutea }}$ & $\begin{array}{c}\text { Percentage } \\
\text { segmented eggs } \\
\text { nb. recovered }\end{array}$ \\
\hline Dry & 36 & $\begin{array}{l}3.4(1-13) \\
3.4(1-9)\end{array}$ & 75 & 61 \\
Nursing & 33 & $58^{*}$ & $40^{*}$ \\
\hline
\end{tabular}

$*: \mathrm{P}<0.01$.

\section{TABLE 8}

Recovery rate after perfusion and fertilization rate of eggs at 7 days after ovulation in dry and nursing Ile-de-France ewes treated during seasonal anoestrus

\begin{tabular}{|c|c|c|c|c|c|}
\hline Exp. & Physiol. state & $\mathrm{Nb}$. of ewes & $\begin{array}{l}\text { Ovulation } \\
\text { rate }\end{array}$ & $\begin{array}{l}\text { Percentage } \\
\text { nb. eggs recovered } \\
\text { total nb. ovulation }\end{array}$ & $\begin{array}{c}\text { Percentage } \\
\frac{\text { nb. fertilized eggs }}{\text { nb. recovered }}\end{array}$ \\
\hline $1\left({ }^{1}\right)$ & $\begin{array}{l}\text { Dry } \\
\text { Nursing }\end{array}$ & $\begin{array}{l}13 \\
24\end{array}$ & $\begin{array}{l}2.7 \\
4.1\end{array}$ & $\begin{array}{l}80 \\
46^{*}\end{array}$ & $\begin{array}{l}48 \\
36 * *\end{array}$ \\
\hline $2\left({ }^{2}\right)$ & $\begin{array}{l}\text { Dry } \\
\text { Nursing }\end{array}$ & $\begin{array}{l}1 / t \\
21\end{array}$ & $\begin{array}{l}3.2 \\
3.2\end{array}$ & $\begin{array}{l}60 \\
55\end{array}$ & $\begin{array}{l}89 \\
58\end{array}$ \\
\hline
\end{tabular}

(1) After flushing of uterine horns.

(2) After ligature of utero-tubal junction and fushing of fallopian tubes.

* : $\mathrm{P}<0.001 ; \quad * *: \mathrm{P}<0.05$. 
was significantly lower in nursing ewes ( 58 p. Ioo vs 75 p. Ioo) (table 7 ) compared with dry ewes. The same was true after recuperation of blastocysts from the uterine horns 7 days after ovulation (table 8). The same tendency was observed when fertilized eggs were recovered from the ligated oviduct, but this was not significant (table 8).

The fertilization rate and the recovery of segmented eggs expressed as a fraction of eggs recovered either two or seven days after ovulation, was always significantly less in nursing ewes. The viability of these segmented eggs evaluated according to the appearance of the 7-day blastocyst (size, absence of pyknosis, formation of the blastocoele) was reduced in lactating animals (table 9). This result was the same, whether the fertilized eggs remained in the ligatured oviduct or in the uterus (HERNANDEZ-BARRETo, I973).

\section{TABLE 9}

Viability of fertilized eggs in dry and nursing Ile-de-France ewes treated during seasonal anoestrus (exp. I + exp. 2 )

\begin{tabular}{l|c|c|c}
\hline Physiol. state & $\begin{array}{c}\text { Nb. fertilized } \\
\text { eggs observed }\end{array}$ & $\begin{array}{c}\text { Percentage } \\
\text { viable eggs } \\
\text { fertilized eggs }\end{array}$ & $\begin{array}{c}\text { Percentage } \\
\text { ewes with one } \\
\text { or more viable eggs }\end{array}$ \\
\hline Dry & 36 & 83 & 65 \\
Nursing & 38 & 35 & 27 \\
\hline
\end{tabular}

An egg transfer experiment from nursing to dry ewes, and inversely, was carried out to try to discover whether, under the conditions of progestagens-PMSG treatment and the 45 days lambing-artificial insemination interval, the quality of the egg released is more or less responsible than the uterine environment for the low fertility in nursing ewes treated during the non-breeding season. The pregnancy rate evaluated at $\mathbf{I} 8$ days by progesterone assay showed a tendency to be lower in dry ewes having received eggs from nursing ewes. The quality of the eggs transferred at two days, and which were always segmented could thus be lower in nursing ewes (table ro). But in the receiver dry ewes, regardless of the origin of the egg (dry or nursing) the pregnancy rate at 18 days was perfectly maintained at 50 days, it decreased however, in nursing ewes having received eggs from dry ewes. This significant difference in the viability of the embryos in the uterine environment of nursing ewes (expressed in number of living embryos at 50 days against segmented eggs transferred) leads to suppose that the environment in which the eggs develop is unfavourable in these animals.

In fact, several causes are implicated in the low fertility of nursing ewes during the anoestrous period, 40-50 days after lambing. As remarked by LOSELEY and LAMming (I968), in nursing, compared with dry ewes, the rate of fecondation of eggs is lower, due to the spread in ovulation and the conditions of sperm transport in the uterus. A larger number of eggs at 7 days show a delay in development and the 
quality of the gamete produced could perhaps be the reason, since this kind of in vivo culture (the survival in the ligatured oviduct) does not modify the evolution of segmented eggs.

\section{TABLE IO}

Pregnancy rate in dry and nursing ewes at 16 and 50 days after reciprocal transfer of eggs aged of 2 days

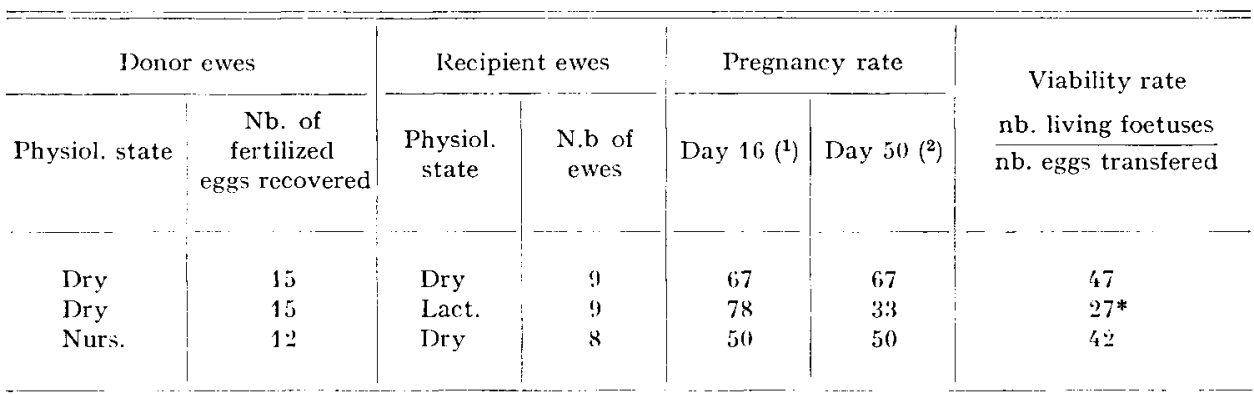

(1) Estimated after assay of plasma progesterone 18 days after induced oestrus (ewe pregnant if concentration $\geqslant 1 \mathrm{ng} / \mathrm{ml}$ ).

$\left({ }^{2}\right)$ After slaughter of ewes.

* : $P<0.01$.

But the greater embryonic mortality produced between the I8th and 5oth day of gestation for eggs transplanted from dry to nursing ewes suggests that not only the quality of the induced ovulation is at fault, but also the uterine environment.

\section{III. - STEROID BALANCE IN NURSING AND DRY EWES}

\section{AFTER PROGESTAGEN-PMSG TREATMENT DURING}

\section{THE NON-BREEDING SEASON}

The evolution of the blood concentration of oestradiol- $\mathrm{I} 7 \beta\left(\mathrm{E}_{2}\right)$ and progesterone (Pg), reflecting respectively follicular growth (BJERSING et al., I972; MoOR, I973; HANSEL, I974; STEAMARK et al., I974) and the activity of the corpus luteum (see review by STABENFELDT, r969), was followed in two groups of Ile-de-France ewes receiving in April-May a progestagen treatment (40 mg, I2 days) and PMSG (600 and $750 \mathrm{IU}$ ) identical to that used previously.

The two steroids were measured in samples of peripheral venous blood obtained from the jugular vein. Hormone assays were carried out by radioimmunoassay with specific antisera and the technique of double antibody precipitation (oestradiol-I7 $\beta$, method of Terour et al., I972, modified by SAUMANDE et al., I975; progesterone-method described by PALMER and JouSSET, I974). Daily blood sampling for I9 days beginning at the onset of the induced oestrus was carried out to assay plasma progesterone in I2 ewes, at least 3 months after parturiton (S) 
and in 24 nursing ewes (A) treated $27 \pm 2$ days after lambing. Although the technique of oestradiol assay allows the assay of as little as $1.6 \mathrm{pg} / \mathrm{ml}$, the concentration of this hormone did not reach this level in some animals. To avoid erroneous interpretation, only 8 animals from the group $S$ and 6 animals from group $A$ will be considered in order that the basal levels of circulating oestradiol are greater than the limit of sensitivity of the assay. Blood sampling from these animals was carried out every two hours during the 48 hours following the end of progestagen treatment.

When it was measurable, the basal level of oestradiol-I7 $\beta$ varied between I-Io $\mathrm{pg} / \mathrm{ml}$. A maximum concentration greater than $6 \mathrm{pg} / \mathrm{ml}$ was measured in 6 out of the 8 dry ewes (group S) and in 3 out of 6 nursing ewes (group A). The highest concentrations measured were $76 \mathrm{pg} / \mathrm{ml}$ and $\mathrm{I} 4 \mathrm{pg} / \mathrm{ml}$ for groupe $\mathrm{S}$ and A respectively; the average values are shown in table I I. Although they were not significant, these values suggest that there are differences in follicular stimulation depending on the presence or absence of lactation or of a lamb. The small number of animals, the variation in individual ovarian state during the anoestrous season, and the variations in ovulation rate in response to hormone treatment are the origins of the lack of a significant difference.

TABLE, I I

Maximum concentration of oestradiol $17 \beta$ in relation to progestagen treatment, onset of oestrus and $L H$ peak

\begin{tabular}{|c|c|c|c|c|}
\hline \multirow{2}{*}{$\begin{array}{c}\text { Physiological state } \\
\text { of females }\end{array}$} & \multirow{2}{*}{$\begin{array}{l}\text { Max. concentration } \\
(\mathrm{pg} / \mathrm{nl})\end{array}$} & \multirow{2}{*}{$\begin{array}{l}\text { After end } \\
\text { of progestagen } \\
\text { treatment }\end{array}$} & \multicolumn{2}{|c|}{$\begin{array}{c}\text { Time of max. concentration (hours) }{ }^{(1)} \\
\text { in relation to onset }\end{array}$} \\
\hline & & & of orstrus & of $\mathrm{l}$ II peak \\
\hline Dry $S(8)$ & $\begin{array}{c}21.8 \pm 8.7 \\
{[1.6-76]}\end{array}$ & $\begin{array}{c}31.8 \pm 1.5 \\
{[2 / 4-38]}\end{array}$ & $\begin{array}{l}5.2 \pm 3 \\
{[-2-16]}\end{array}$ & $\begin{array}{l}11 \pm 3.1 \\
{[1-20]}\end{array}$ \\
\hline Nursing A (6) & $\begin{array}{l}6.8 \pm 2.2 \\
{[1.5-14]}\end{array}$ & $\begin{array}{l}29 \pm 3.3 \\
{[16-38]}\end{array}$ & $\frac{8 \pm 4.8}{[0-2 \cdot 2]}$ & $\begin{array}{l}3 \pm 7 \\
{[4-3,1]}\end{array}$ \\
\hline $\begin{array}{l}\text { (1) Mean } \pm \text { S. } \\
(\quad): \text { No. of anim } \\
{[\quad]: \text { Limits. }}\end{array}$ & & & & \\
\hline
\end{tabular}

The maximum concentration of oestradiol-I $7 \beta$ appears on average 30 hours after the end of progestagen treatment, that is between 5 an 8 hours before the onset of oestrus, and II-I3 hours before the LH peak. HANCOCK et al. (I970), in the amennorheic patient treated with gonadotrophins, and SAUMANDE and PeLLETIER (I975), in the cow superovulated with PMSG, have shown that the coefficient of regression of the logarithm of the concentration of oestradiol-I $7 \beta$ with time during the period which preceed the $\mathrm{LH}$ discharge is a good indication of follicular growth. In comparing the two categories of ewe, the regression previously defined does not occur in nursing ewes, but is significant in 7 out of I I cases in the dry ewes, and above all, in 
those which were pregnant (table 12 ). The overall picture presented by these preliminary results shows that the production of oestradiol-I $7 \beta$ by follicles induced to grow in dry ewes appears more "normal" than in nursing ewes (fig. 2).

TABIE I2

Logarithm of oestradiol concentration as a function of time during the 24 bours before the $L H$ peak

\begin{tabular}{|c|c|c|c|c|c|c|c|}
\hline $\begin{array}{c}\text { Physiological } \\
\text { state }\end{array}$ & $\begin{array}{l}\text { No of } \\
\text { ewes }\end{array}$ & $\begin{array}{c}\text { Correlation } \\
\text { oestra- } \\
\text { diol-f }(\mathrm{t})\end{array}$ & $\begin{array}{l}\text { Signifi- } \\
\text { cance }\end{array}$ & $\begin{array}{c}\text { Physiological } \\
\text { state }\end{array}$ & $\begin{array}{l}N^{0} \text { of } \\
\text { ewes }\end{array}$ & $\begin{array}{c}\text { Correlation } \\
\text { oestra- } \\
\text { diol-f }(t)\end{array}$ & $\begin{array}{l}\text { Signifi- } \\
\text { cance }\end{array}$ \\
\hline \multirow[t]{3}{*}{ Dry } & & & & Nurrsing & & & \\
\hline & 1 & $0.4_{4}^{4}$ & 0.1 & & 1 & 0.25 & n.s. \\
\hline & 2 & $(0.80)$ & 0.01 & & 2 & 0.16 & n.s. \\
\hline \multirow[t]{4}{*}{ Pregnant } & 3 & $0.4 / \mathbf{t}$ & 0.1 & Pregnant & 3 & 0.32 & n.s. \\
\hline & 1 & 0.47 & 0.1 & & 4 & $(0.65)$ & 0.02 \\
\hline & 5 & 0.70 & 0.01 & & 5 & $(0.41)$ & n.s. \\
\hline & 7 & 0.13 & n.s. & & 6 & $(0.01)$ & n.s. \\
\hline \multirow{3}{*}{ non-pregnant } & 8 & 0.85 & 0.01 & non-pregnant & 7 & $(0.26)$ & n.s. \\
\hline & 9 & $(0.17)$ & n.s. & & 8 & $(0.28)$ & n.s. \\
\hline & 10 & 0.03 & n.s. & & & & \\
\hline
\end{tabular}

( ) Slope of regression line negative, considered as not significant.

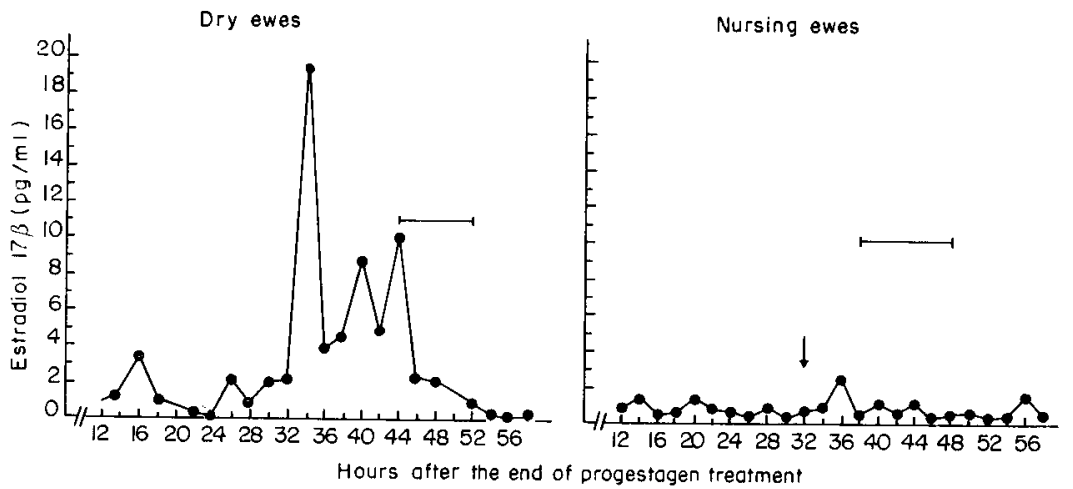

Ewe No. 6

Sensitivity $10 \mathrm{pg}$

Ewe No. 2

Sensitivity $1,6 \mathrm{pg}$

FIG. 2. - Evolution of oestradiol-17 $\beta$ concentration

The curves of the evolution of plasma progesterone in these dry and nursing ewes are presented in figure 3 . In all cases, the level of progesterone increases between Days 4 and ro and in most animals, maximum concentrations are observed at this time (72 p. Ioo for group S and 67 p. Ioo for group A). During this phase of 
evolution, the daily plasma progesterone concentration is related to the number of induced corpora lutea $(r=0.98)$, but only in those dry and nursing ewes which are pregnant. It could be supposed that in non-pregnant ewes, the function of all corpora lutea does not occur normally. A linear relation between the increase in oestradiol-I $7 \beta$ during the 24 hours before the LH peak, and the increase in progesterone during Days 4-IO after ovulation is very marked in the dry ewes $(r=0.9)$ but does not occur in nursing ewes, showing that the function of the corpus luteum depends on the quality of follicular stimulation.

An important difference appears between pregnant animals of the two groups - dry and nursing - ewes (fig. 3) during the second period (IO-I4 days) of the gestation, the period which precedes luteolysis at the I5th day and the decrease in progesterone. For an equal mean number of corpora lutea, the daily plasma concentration of progesterone is always less in nursing females. This difference in progesterone concentration may be related to the high embryonic mortality after Day I9 of gestation, observed in pregnant, nursing ewes, and according to the pregnancy diagnosis, and having the life span of the corpus luteum prolonged by the presence of a foetus.

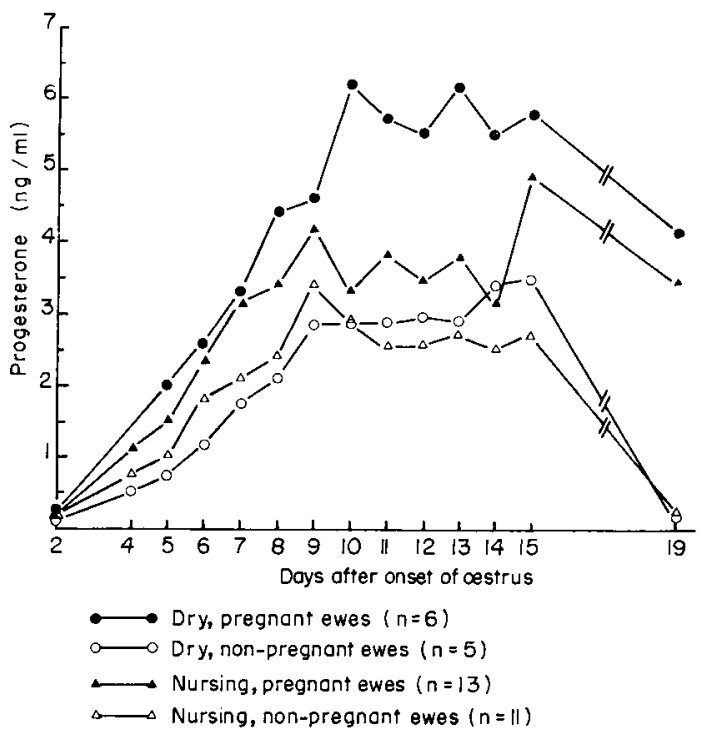

FIG. 3. - Evolution of plasma progesterone in dry and nursing e'飞es

In conclusion, although these results can only be considered as preliminary, the reduced oestrogenic response by the ovary to progestagen-PMSG treatment is to be expected in nursing ewes during the non-breeding season. Lactation could disturb the function of the ovary, as has been observed in lactating women (ZARATE et al., I972). But it would be useful to know if it is a question of a numerical modification in the follicular population, thus, the basal level of FSH and $\mathrm{LH}$, or of ovarian follicular receptors to the hormones stimulating them. It is equally likely that a decreased pre-ovulatory increase in oestrogens is responsible for the decrease 
in the LH discharge in the nursing ewes (PELLETIER and THIMONIER, I973; CogNIE and PELLETIER, I975; LEWIS et al., I974), since the discharge of LH induced by LH-RF in the nursing ewe represents only $60 \mathrm{p}$. Ioo of that induced in dry ewes during the non-breeding season. The decrease in this response in ewes in lactation is not simply due to a simple effect of $\mathrm{L}, \mathrm{RF}$, but is a result of an interaction of LRF with other hormones, including the oestrogens (PELLETIER and THIMONIER, I975). The period of insensitivity of the hypophysis to LH-RF found in lactating women (LEMAIRE et al., I974) is certainly due to the same original cause.

The curve of the evolution of progesterone concentration in dry and nursing ewes treated with progestagens and PMSG are identical to those described for different breeds of sheep during the breeding season (STABENFELDT, I969; THORBURN et al., I969; McNATTY et al., I973; SARDA et al., I973).

The levels of plasma progesterone are lower between the Io-I4th days of the cycle in pregnant nursing ewes than in dry pregnant ewes; pregnancy in lactating animals has not the precocious effect of an increase in the level of progesterone which is observed in dry ewes. This reduction in the concentration of progesterone could be due to a difference in the metabolism of this hormone in lactating ewes (BEDFORD et al., I972). This difference in hormone levels over a short period important for the future of the corpus luteum renders plausible the hypothesis of a modification in its function.

Colloque : Control of sexual cycles in domestic animals October 29-30, 1974, Nouzilly.

\section{RÉSUMÉ}

\section{FAIBIE FERTILITÉ DES BREBIS ALLAITANTES MISES A IA REPRODUC'TION EN CONTRE-SAISON}

Estrus et ovulation sont bien contrôlés chez la Brebis de race Ile-de-France à saison sexuelle marquée par un traitement progestagène PMSG, quel que soit le mois de l'année, mais la fertilité après IA à l'œstrus induit augmente avec l'intervalle mise bas-insémination artificielle aussi bien au printemps qu'à l'automne. Les taux d'agnelage après des IA 45 jours ou 70 jours après la mise bas sont respectivement en automne $45 \mathrm{p}$. Ioo vs $7^{\circ} \mathrm{p}$. Ioo, au printemps 27 vs $46 \mathrm{p}$. Ioo.

Dans le cas d'un intervalle parturition-insémination artificielle de 45 jours nécessaire pour un programme de double agnelage par an, les plus faibles fertilités sont trouvées chez les brebis allaitantes pendant la période d'anœstrus.

Lorsque la Brebis allaite deux agneaux, cette fertilité à l'œestrus induit est plus faible que si elle en allaite un seul en particulier au printemps (48 p. Ioo vs $6 \mathrm{I}$ p. Ioo). Une étude physiologique a été conduite dans les deux cas extrêmes brebis sèches et brebis allaitantes de race $I l e-$ de-France recevant le traitement progestagène PMSG pendant les mois de mars à mai.

Les taux de récupération des oufs à 2 jours (58 vs $75 \mathrm{p}$. Ioo) ou des blastocystes à 7 jours (46 vs 80 p. IOo) après l'ovulation sont plus faibles chez les brebis allaitantes que chez les brebis sèches. Les taux de fécondation à ces mêmes moments varient de la même façon..

Une expérience de transfert réciproque d'œufs de brebis allaitantes chez des sèches montre que la qualité des œufs obtenus chez les allaitantes peut être impliquée comme cause de faible fertilité. Toutefois, il apparaît aussi de cette expérience de transfert que la qualité de l'environnement utérin est certainement défavorable chez ces brebis allaitantes : une plus grande mortalité embryonnaire entre 18 et 50 jours se produit lorsque des œufs de brebis sèches sont transférés chez des brebis allaitantes que s'ils le sont chez des brebis sèches... Par ailleurs, un plus grand nombre de blastocystes 7 jours après l'ovulation sont en retard de développement et la viabilité des œufs fécondés chez ces brebis allaitantes est réduite.

La balance endocrine qui précède et suit l'ovulation est différente chez les brebis allaitantes 
comparée à celle des brebis sèches : la décharge préovulatoire d'œstrogènes reflet de la stimulation folliculaire n'évolue pas et n'atteint pas un niveau aussi élevé chez les allaitantes que chez les brebis sèches. Le taux de progestérone plasmatique est corrélé au taux d'oestradiol-I7 $\beta$ plasmatique au cours des 24 heures qui précèdent le pic de LH. Enfin, la concentration plasmatique de progestérone entre le Io $^{\mathrm{e}}$ et le $\mathrm{I}_{4}{ }^{\mathrm{e}}$ jour de la gestation est plus faible chez les brebis allaitantes que chez les sèches.

\section{REFERENCES}

BedFord C. A., Harrison S. A., HEAP R. B., I972. The metabolic clearance rate and production rate of progesterone and the conversion of progesterone to $20 x$-hydroxy-pregn, 4 , en 3 one in the sheep. J. Endocr., 55, 105-118.

Bjersing L., Hay M. F., Kani G., Moor R. M., Naftolin F., Scaramuzzi R. J., Short R. V., Younglai E. V., 1972. Changes in gonadotrophins ovarian steroids and follicular morphology in sheep at oestrus. J. Endocr., 52, 465-479.

Choffardet R., I97I. L'anœstrus de lactation pendant l'anœstrus saisonnier chez la Brebis. Diplôme. de fin d'Études, F. N.S. A., Nancy.

Cognie Y., Colas G., ig68. Evolution des techniques de reproduction ches les ovins. Pâtre, 153, $17 \cdot 24$.

Cognie Y., CoRne C., Mauleon P., I974. The influence of lactation on fertility of ewes treated during post-partum anoestrus with vaginal sponges impregnated with FGA. Symp. Physiopathology of Reproduction and $A I$, Thessaloniki, I7-I9 mai I 974 .

Cognie Y., Pelletier J., I975. Preovulatory LH release and ovulation in dry-ewes and lactating ewes after progestagen and PMSG treatment during the seasonal anoestrus period. Ann. Biol. Bioch. Biophys. (sous presse)

Colas G., Brice G., Courot M., Cotrier M., I971. L'insémination artificielle dans les plans d'intensification de la production ovine : état actuel et perspectives. Bull. Tech. Inf., 25\%, I-6.

Foote W. C., 197I. Some influences of lactation and hormone treatment on uterine changes in postpartum sheep. J. Anim. Sci., 32, suppl. I, 48-54.

Hancock K. W., Stitch S. R., OAxey R. E., Scott J. S., I97o. Ovulation stimulation. Problems of prediction of response to gonadotrophir. Lancet, ii, 482-484.

Hansel W., 1975. Luteal regression in domestic animals. Ann. Biol. anim. Bioch. Biophys., 15, I47-I60.

Hernandez-Barreto M., I973. Développement de l'œuf chez la Brebis allaitante pendant l'anœstrus saisonnier. (non publié).

Hulet C. V., Stormshak F., 1972. Some factors affecting response of anoestrous ewes to hormone treatment. J. Anim. Sci., 34, IOII-IOIg.

Le Maire W. J., Shapiro A. G., Rigali F., Yang N. S. T., I974. Temporary pituitary insensitivity to stimulation by synthetic LRF during the post-partum period. J. Clin. Endocr. Met, 38,916-918.

LEwIS P. E., BOLT D. J., INSKEEP E. K., I974. Luteinizing hormone release and ovulation in anoestrous ewes. J. Anim. Sci., 38, II97-1203.

Moseley S., Laming G. E., r968. The fertility of sheep induced to breed during lactation. I' I Cong. Intern. Reprod. Anim. Insem. Artif., Paris, vol. II, I487-1489.

McNatty K. P., Revfeim K. J. A., Young A., i973. Peripheral plasma progesterone concentrations in sheep during the oestrous cycle. J. endocr., 58, 2 19-225.

MaUi,eon P., Flamant J., I975. Pourquoi allaiter artificiellement. In : L'allaitement artificiel chez les ovins, Ed. S. E. I.-I. N. R. A., Paris, mars 75.

Moor R. M., I973. Oestrogen production by individual follicles explanted from ovaries of sheep. $J$. Reprod. Fert. 32, 545-548.

Palmer E., Jousset B., I974. Urinary oestrogen and plasma progesterone levels in cyclic and non cyclic mares. First Intern. Symp. upon Equine Reprod., Cambridge (G. B.) (sous presse).

Pelletier J., Thimonier J., r973. Comparison of the induced preovulatory LH discharge in lactating and dry sheep during seasonal anoestrus. J. Reprod. Fert., 33, 310-313.

Pelletier J., Thimonier J., I975. Interactions between ovarian steroids or progestagens and LH release. Ann. Biol. anim. Bioch. Biophys., 15, 131-146.

Prayer C., 1972. Étude du moment de l'ovulation de la fécondation et du développement de l'œuf chez la Brebis allaitante pendant l'anœstrus saisonnier. Mémoire fin d'Études E. N. S. A., Nancy.

Sarda J. R., Robertson H. A., Smeaton T. C., I973. Sequential changes in plasma progesterone levels in the ewes during the estrous cycle and during pregnancy in intact and ovariectomized sheep. J. Anim. Sci., 53, 25-34.

Saumande J., Hernandez-Barreto M., André D., I975. Dosage radioimmunologique de l'estradiol-17 $\beta$. Améliorations techniques et diminution du prix de revient de la méthode. Pathol. Biol. (sous presse). 
Saumande J., Pelletier J., i975. Relationship of plasma levels of $\propto$ stradiol-i 73 and luteinizing hormone with ovulation rate in pregnant mare serum superovulated cattle. J. Endocr., 64, I89-I9o.

Seamark R. F., Moor R. M., McIntosh J. E. A., I974. Steroid hormone production by sheep ovarian follicles cultured in vitro. J. Reprod. Fert., 41, I43-I 58.

Signoret J. P., Cognie Y., I975. Determination of the moment of ovulation in ewe and sow. Influence of environment and hormonal treatment. Ann. Biol. anim. Bioch. Biophys., 15, 205-2I4.

Stabenfeldt G. M., Molt J. A., Ewing L. I., ig69. Peripheral plasma progesterone levels during the ovine estrous cycle. Endocrinology, 85, II-I5.

Teroui M., Dray F., Cotta J., I973. Variations de la concentration de l'œstradiol-I $7 \beta$ dans le sang périphérique de la brebis au cours du cycle cestral. C. R. Acad. Sci. (Paris), D, 27\%, I795-1798.

Theriez M., Molenat J., I975. Conduite intensive des troupeaux ovins. Effet du tarissement dès la mise bas sur la fécondité de brebis inséminées tous les 6 mois. Ann. Zootech. (sous presse).

Thimonier J., Mauleon P., Cognie Y., Ortavant R., ig68. Déclenchement de l'œstrus et obtention de la gestation pendant l'anœestrus post-partum chez la Brebis à l'aide d'éponges/vaginales imprégnées d'acétate de fluorogestone. Ann. Zootech., 17, 257-273.

Thimonier J., Mauleox P., ig69. Variations saisonnières du comportement d'cestrus et des activités ovarienne et hypophysaire chez les ovins. Ann. Biol. anim. Bioch. Biophys., 9, 233-252.

Thimonter J., Cognie Y., 1971. Accélération des mises bas et conduite d'élevage chez les ovins. Bull. Tech. Inform. Minist. Agric., 257, I-IO.

Thorburn G. D., Basset J. M., Smith I. D., I969. Progesterone concentration in the peripheral plasma of sheep during the oestrous cycle. J. Endocr., 45, 459-469.

Zarate A., Canales E. S., Sour J., Ruiz F., McGregos C., I972. Ovarian refractoriness during lactation in women : effect of gonadotropin stimulation. Amer. J. Obstet. Gynec., 112, II3O-II3I. 